Gut, 1985, 26, 285-290

\title{
Impaired suppressor activity in children affected by coeliac disease
}

\author{
C PIGNATA, R TRONCONE, G MONACO, M CIRIACO, E FARRIS, \\ G CARMINATI, AND S AURICCHIO
}

From The Department of Pediatrics, 2nd School of Medicine, University of Naples, Naples, and Immunohematology Research Center, Avis, Bergamo, Italy.

SUMMARY Immunoregulatory cells were enumerated in 19 coeliac disease children on a gluten free diet by means of monoclonal antibodies that define total T lymphocytes (T3), helper/inducer T cells (T4), suppressor/cytotoxic T cells (T8) and monocytes (M1), as well as by means of surface receptors for Fc fragments of IgM and IgG (T $\mu$ and $\mathrm{T} \gamma$, respectively). In addition, suppressor cell function was assessed in 17 coeliac disease patients by examining the ability of concanavalin-A (Con-A)-activated suppressor cells to inhibit autologous cell response to mitogenic stimulus as compared with age-matched controls. No statistically significant differences were found in the percentages of subsets defined by monoclonal antibodies between coeliac disease patients and age-matched controls, whereas coeliac disease patients had a significant decrease of the subpopulation bearing membrane receptor for Fc fragment of IgG. Mean value was $8.5 \%$ in coeliac patients versus $13.4 \%$ in age-matched controls. In the functional assay, mononuclear cells from 10 out of 17 coeliac disease patients either totally or partially failed to suppress responder cells after Con-A-activation. This defect is not related to HLA-DR status, because no difference was found between patients-HLA-matched and unmatched normal individuals. In this assay, mononuclear cells of three coeliac disease patients with low suppressor activity were able to inhibit responder cells to the same extent as controls, when indomethacin was used to block prostaglandin production in the induction phase of Con-A-activated suppressor cells. Our results suggest that an abnormality in immunoregulation may play a role in the pathogenesis of coeliac disease.

The mechanism of gluten toxicity in coeliac disease is unknown. Evidence is accumulating that cell mediated and humoral immune mechanisms may play a role in the pathogenesis of the disease. Intestinal intraepithelial infiltrates of lymphocytes or other mononuclear cells, and immunoglobulin synthesis in the gut mucosa of coeliac patients after gluten challenge have been reported. ${ }^{12}$ Lymphocytes from coeliac disease patients on a gluten free diet react with a proliferative response to gluten stimulation in vitro. ${ }^{3-7}$ Sensitisation of blood leukocytes from coeliac disease patients to gluten fraction III was also shown by measuring leukocyte migration inhibition. ${ }^{8}$

On the other hand, a hyperactivity of $B$ lymphocytes has been supposed from the presence

Address for correspondence: Claudio Pignata, MD, Clinica Pediatrica, II Facoltà di Medicina di Napoli, Via S Pansini, 5-80131 Napoli, Italy.

Received for publication 1 June 1984 of autoantibodies in the serum of a few coeliac disease patients, ${ }^{910}$ and from high antibody responses to some dietary antigens. ${ }^{11}$ The latter phenomenon was interpreted as a consequence of mucosal damage that allows dietary antigens to reach peripheral blood. Another possible explanation is that a defect of immunoregulatory cells may affect immune response to gluten and other antigens.

A positive association of HLA-B8, DRw3 and more recently DC 3 with coeliac disease has been noted. ${ }^{12-17}$ Furthermore sensitisation of blood leukocytes to gluten fraction III was also shown in normal HLA-B8-positive controls. ${ }^{8}$ This evidence suggested the presence of immune response genes (Ir) in linkage disequilibrium with HLA-B8, which modulate immune response to gluten. ${ }^{8}$

In our region, $98 \%$ of coeliac disease patients are DR 3- and/or 7-positive. ${ }^{17}$ Because DR genes, 
analogous to the murine Ia genes, are putatively immunoregulatory genes, the prevalence of DR 3 and/or 7 may affect immune response to wheat protein. A previous study on immunoregulation in adult coeliac disease showed a defective suppressor activity of short lived suppressor cells. ${ }^{18}$

In the present study Con-A-induced suppressor cells and $\mathrm{T}$ cell subsets were investigated in 17 and 19 coeliac disease children, respectively. Results were compared with age-matched controls; functional assay was also performed in HLA-DR 3and 7-positive adult controls and compared with randomly selected controls.

\section{Methods}

\section{SUBJECTS}

Three groups of subjects were studied. The first group consisted of 19 and 17 coeliac disease patients in remission on a gluten free diet for at least five months, who were investigated for $T$ cell subsets and suppressor activity, respectively. All patients were in good nutritional status. Mean age was 6.2 years, ranging between 2 and 12 years. Diagnosis was based on the following criteria: all patients during the active phase of the disease had the typical clinical and histological findings; other possible causes of subtotal atrophy of the small intestinal mucosa were excluded. In all cases a gluten free diet resulted in normalisation of the clinical symptoms, of the malabsorption tests and of the histological features of small intestinal biopsies. In six cases sufficient time elapsed from the beginning of our study to permit gluten challenge and all these cases showed histological relapse of the disease. ${ }^{19}$ The second group consisted of age-matched controls. The last group consisted of unselected healthy adult controls and HLA-DR 3- and/or 7-positive adult controls.

ISOLATION OF PERIPHERAL BLOOD MONONUCLEAR CELLS

Heparinised venous blood samples were collected when follow up of coeliac disease patients required evaluation of nutritional status; a plasma was used for routine laboratory examinations, cell pellet resuspended in RPMI 1640 was centrifuged on a Ficoll/Hypaque density gradient to obtain mononuclear cells. Cells were washed three times with calcium and magnesium-free Hank's balanced salt solution (HBSS), resuspended in RPMI 1640 containing $15 \%$ foetal calf serum and processed as described below.

PREPARATION OF T CELL ENRICHED SUSPENSION $\mathrm{T}$ enriched population was obtained by centrifuging on Ficoll-Hypaque gradient lymphocytes rosetted with neuraminidase-pretreated sheep red blood cells. ${ }^{20}$ The erythrocytes, after sedimentation, were lysed in $0.87 \% \mathrm{NH}_{4} \mathrm{Cl}$. These suspensions contained more than $95 \%$ of rosette forming cells.

ANALYSIS OF CELL SUBSETS BY MONOCLONAL ANTIBODIES

Monoclonal antibodies of the OKT series (Ortho Pharmaceutical, Raritan, NJ) against surface antigens of mononuclear cells were used. T lymphocytes reacted with anti-T3; ${ }^{21}$ anti-T4 and anti-T8 defined helper/inducer and suppressor/ cytotoxic T lymphocytes, respectively. ${ }^{22}{ }^{23}$ Anti-T6 defined a thymus specific antigen expressed on $70 \%$ of thymocytes and lacking on peripheral lymphocytes. $^{24}$ OKM1 was used to characterise monocytes and killer cells. ${ }^{25}$ Finally, a monoclonal antibody reactive with an invariant region of HLADR was used. This monoclonal antibody is reactive with all peripheral $B$ lymphocytes, with a fraction of null cells and with activated T cells. ${ }^{26}$ Analysis was performed by indirect immunofluorescence with fluorescein-conjugated goat antimouse IgG (Meloy Laboratories, Springfield, Va.) at a final dilution of 1:50 using a Zeiss immunofluorescence microscope.

DETECTION OF T $\gamma$ AND T $\mu$ SUBSETS

Previously reported methods were used to enumerate $\mathrm{T} \gamma$ and $\mathrm{T} \mu$ subpopulations. ${ }^{27}$ Briefly, $\mathrm{T} \gamma$ cells were detected by rosette formation with ox erythrocytes (ORBC) coated with subagglutinating amounts of IgG fraction of rabbit anti-ORBC antibodies (EA-IgG); the mixture of purified $\mathrm{T}$ lymphocytes and EA-IgG in RPMI 1640 was centrifuged at $200 \mathrm{~g}$ for five minutes, followed by incubation at $4^{\circ} \mathrm{C}$ for at least one hour. The pellet was resuspended and 200 or more cells were counted. Cells with three or more EA-IgG attached were considered $\mathrm{T} \gamma$. Similarly, $\mathrm{T} \mu$ were detected by rosette formation with ORBC coated with antiORBC IgM antibodies (EA-IgM); purified T cells were previously cultured at a concentration of $10^{6} / \mathrm{ml}$ in $5 \% \mathrm{CO}_{2}-95 \%$ air at $37^{\circ} \mathrm{C}$ in RPMI 1640 supplemented with $15 \%$ fetal calf serum. The $\mathrm{T}$ lymphocyte-EA-IgM mixture was centrifuged for five minutes at $200 \mathrm{~g}$ and incubated for at least one hour at $4^{\circ} \mathrm{C}$. The pellet was resuspended and the cells scored in a haemocytometer.

SUPPRESSOR CELL FUNCTION

Unfractionated mononuclear cells resuspended in RPMI 1640 medium containing $15 \%$ fetal calf serum, gentamycin $1 \mu \mathrm{g} / \mathrm{ml}$ and glutamine $1.5 \mathrm{mM}$, were separated in three aliquots at a final concentration of $3.5 \times 10^{6}$ cells $/ \mathrm{ml}$. One of these maintained at 
room temperature was used as responder cells after adjusting to a concentration of $1 \times 10^{6} \mathrm{cells} / \mathrm{ml}$. To the other aliquots either Con-A, at a final concentration of $20 \mu \mathrm{g} / \mathrm{ml}$, or medium was added. ${ }^{28}$ They were incubated for $48 \mathrm{~h}$ at $37^{\circ} \mathrm{C}$ in $5 \% \mathrm{CO}_{2}$ and then treated with mitomycin $\mathrm{C}\left(50 \mu \mathrm{g} / \mathrm{ml}\right.$ at $37^{\circ} \mathrm{C}$ for 30 min, Sigma), washed three times in HBSS and resuspended in complete culture medium at a final concentration of $1 \times 10^{6} \mathrm{cells} / \mathrm{ml}$. In some experiments to exclude interference of prostaglandin-mediated suppression on Con-Ainduced suppressor activity, ${ }^{29}$ a fourth aliquot of mononuclear cells at a concentration of $3.5 \times 10^{6}$ cells $/ \mathrm{ml}$ was incubated for 48 hours with Con-A (20 $\mu \mathrm{g} / \mathrm{ml})$ and indomethacin $(1 \mu \mathrm{g} / \mathrm{ml})$. In preliminary experiments the cell viability after preincubation was assessed by exclusion of trypan blue dye: it was always higher than $97 \%$.

The various lymphocyte preparations were then cultured in complete tissue culture medium at $1 \cdot 10^{6}$ cells $/ \mathrm{ml}$. Each well contained $100 \mu \mathrm{l}$ autologous responder cells, $100 \mu \mathrm{l}$ Con-A-induced suppressor cells or non-Con-A-preincubated control cells. 12.5 $\mu \mathrm{l} \mathrm{Con-A}$ at a final concentration of $6 \mu \mathrm{g} / \mathrm{ml}$ of culture suspension was then added directly to all wells as a mitogen. Cells were cultured in microtitre plates at $37^{\circ} \mathrm{C}$ in $5 \% \mathrm{CO}_{2}$; the cultures were pulsed at $48 \mathrm{~h}$ with $0.5 \mu \mathrm{Ci}\left({ }^{3} \mathrm{H}\right)$ thymidine (Amersham International, UK) and harvested at $72 \mathrm{~h}$ with a harvester (Flow Laboratories Inc.). All cultures were performed in triplicate. Results are expressed as percentage of suppression calculated as follows:

cpm (stimulated - unstimulated)

in the presence of Con-A-treated cells

cpm (stimulated - unstimulated)

in the presence of Con-A-untreated cells

STATISTICAL ANALYSIS

Difference between patients and controls for $T$ subset variables was calculated by Student's $t$ test, and for functional assay also by the Mann-Whitney test. The frequency of abnormal values of suppressor activity was calculated by a $2 \times 2$ contingency table and $\chi^{2}$ test.

\section{Results}

CIRCULATING T SUBSETS DEFINED BY MONOCLONAL ANTIBODIES

As shown in Table 1, in normal children $56 \pm 3 \%$ of peripheral mononuclear cells were reactive with the OKT3 monoclonal antibody, which defines total peripheral $\mathrm{T}$ cells; within $\mathrm{T}$ subset $57 \pm 10 \%$ and $25 \pm 7 \%$ were positive with the OKT4 and OKT 8 monoclonal antibodies, which define helper/inducer
Table 1 Percentage of circulating T subsets defined by monoclonal antibodies in coeliac patients and controls $(\text { mean } \pm S D)^{*}$

\begin{tabular}{lclcc}
\hline & $T 3$ & \multicolumn{1}{c}{$T 4$} & \multicolumn{1}{c}{ T8 } & $\begin{array}{c}\text { Ratio } \\
\text { T4/T8 }\end{array}$ \\
\hline Patients $(\mathrm{n}=18)$ & $53 \pm 6$ & $50 \pm 6$ & $26 \pm 9$ & $2 \cdot 16 \pm 0 \cdot 99$ \\
Controls $(\mathrm{n}=10)$ & $56 \pm 3$ & $57 \pm 10$ & $25 \pm 7$ & $2 \cdot 43 \pm 1 \cdot 00$ \\
\hline
\end{tabular}

* T3 values are expressed as percentage of positive cells on unfractionated mononuclear cells, whereas T4 and T8 values are expressed as percentages of positive cells on T-enriched

populations. Differences between coeliac patients and age-matched controls are not statistically significant.

and suppressor/cytotoxic lymphocytes, respectively. $T$ subsets in coeliac disease patients were not statistically different from those in controls, mean values being $53 \pm 6 \%, 50 \pm 6 \%$, and $26 \pm 9 \%$ for $\mathrm{T} 3$, $\mathrm{T} 4$, and T8 cells, respectively. In coeliacs and in controls T lymphocytes reactive with OKT6 monoclonal antibody, which recognises the T6 antigen present on human thymocytes, were absent. In coeliacs, $T$ cells bearing Ia-like molecule, putatively activated $T$ cells $(0.6 \pm 0.5 \%)$, and percentage of monocytes (OKM1 + cells) $(14 \pm 4 \%)$ did not differ from those found in controls $(0.4 \pm 0.5 \%$ and $16 \pm 6 \%$, respectively).

\section{CIRCULATING T SUBSETS DEFINED BY FC}

RECEPTORS FOR IgM AND IgG

$\mathrm{T} \mu$ and $\mathrm{T} \gamma$ were analysed in 19 coeliac patients and compared with controls. The percentage of $T \mu$ cells in the group of patients was not statistically different from that in controls: $59 \pm 19 \%$ versus $50 \pm 14 \%$. On the contrary, a significant reduction in the percentage of $\mathrm{T} \gamma$ cells was observed in patients (Table 2): $8 \pm 7 \%$ versus $13 \pm 6 \%$ of controls $(p<0.05)$.

\section{CON-A-INDUCIBLE SUPPRESSOR ACTIVITY}

Suppressor activity of coeliac patients was lower than that of age-matched controls (mean value \pm

Table 2 Percentage of peripheral blood E-rosetting cells with surface receptors for Fc fragment of Ig in coeliac patients and controls (mean $\pm S D$ )

\begin{tabular}{lcc}
\hline & $T \mu$ & $T \gamma$ \\
\hline Patients $(n=19)$ & $59 \pm 19$ & $8 \pm 7^{*}$ \\
Controls $(n=24)$ & $50 \pm 14$ & $13 \pm 6$ \\
\hline
\end{tabular}

* Statistically significant difference $(p<0.05)$ between patients and controls. 


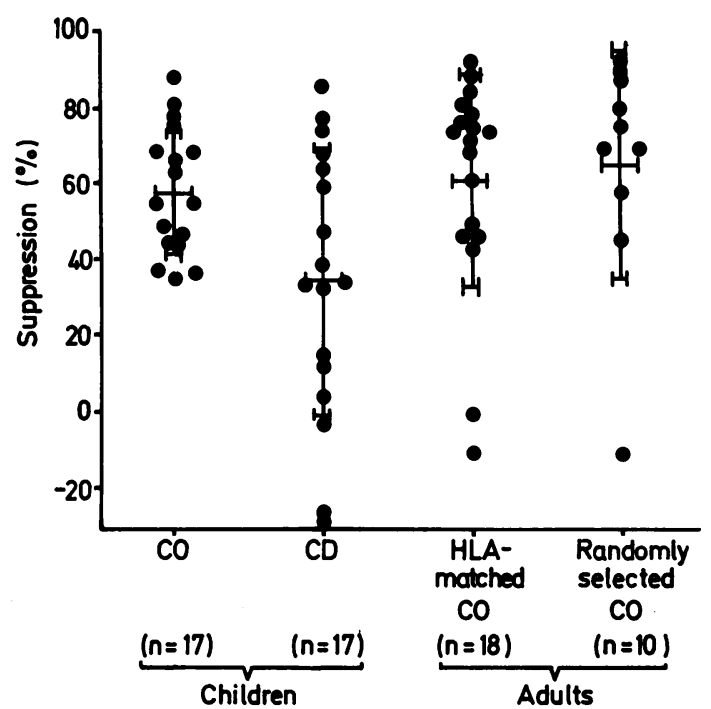

Fig. 1 Con-A-induced suppressor activity in children affected by coeliac disease (CD), age-matched controls (CO), adult controls HLA-matched with patients - that is, $H L A-D R 3$ and $D R 7$, and randomly selected adult controls. Results are expressed as percentage of suppression. Each point represents a single value. Horizontal and vertical bars represent mean $\pm 1 S D$

SD $35 \pm 35 \%$ versus $58 \pm 16 \%$; $p<0 \cdot 02$ ) (Fig. 1). Ten out of 17 patients showed a suppressor activity lower than mean values minus $1 \mathrm{SD}$ of the control group $(p<0.01)$. In some experiments, in the induction phase of Con-A-generation of suppressor cells, indomethacin was added to annul the effect of prostaglandin $\mathrm{E}$, which is considered to be a mediator of adherent-cell-mediated suppression. ${ }^{29}$ Mononuclear cells from three coeliac disease patients after Con-A-activation showed no, or depressed (14\% and 34\%) suppressor activity; indomethacin restored the suppressor activity of the mononuclear cells of these patients to normal values (59\%, $87 \%$, and $50 \%$, respectively) (Fig. 2). In seven normal age-matched controls indomethacin exerted different effects: in four subjects it slightly enhanced suppression, whereas in three subjects it did not (suppression was $62.95 \pm 20.22 \%$ versus $54.71 \pm 15.48 \%$ in the absence of indomethacin; $\mathrm{p}=\mathrm{N} \mathrm{S})$.

\section{CON-A-INDUCED SUPPRESSOR ACTIVITY AND} HLA-DR ANTIGENS

To correlate Con-A-induced suppressor activity to DR status we compared healthy HLA-DR 3and/or 7-positive adult subjects to randomly selected adult volunteers. There was no significant difference between the two groups (see Fig. 1).

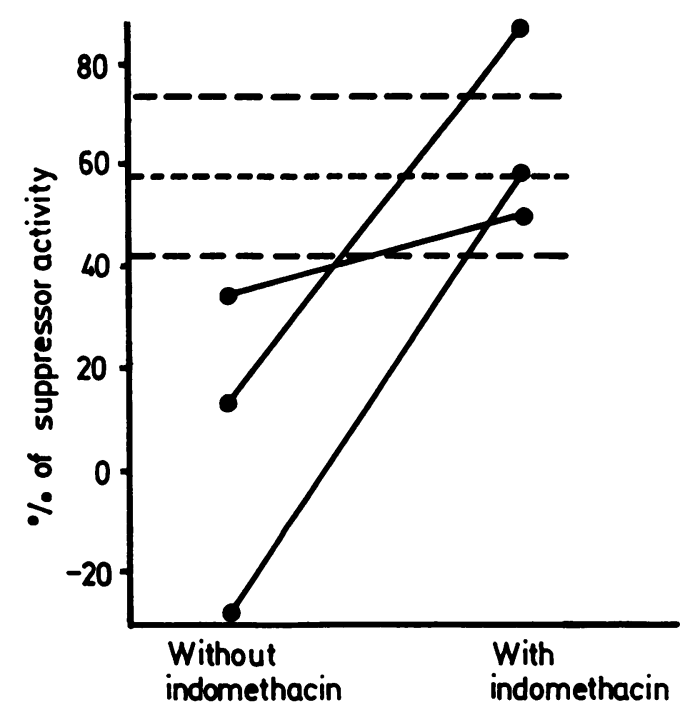

Fig. 2 Normalisation by indomethacin of Con-A-induced suppressor activity in three coeliac patients. Dotted lines represent mean $\pm 1 S D$ of control values

\section{Discussion}

It is known that Con-A induces suppressor activity in normal subjects. ${ }^{28}$ The property to generate suppressor activity has been recently attributed to T8 phenotype $\mathrm{T}$ cells, the suppressor/cytotoxic cells. ${ }^{23}$ These cells are thought to be responsible for either suppression of cell-mediated and humoral immune response or cell-mediated lympholysis. Previously, $\mathrm{T}$ cells bearing surface receptors for Fc of $\operatorname{IgG}(\mathrm{T} \gamma)$ were also claimed to be responsible for suppressor activity. Reinherz et $a l^{30}$ have recently provided evidence that $\mathrm{T}^{+}$and $\mathrm{T} \gamma$ are different subsets, the latter being a heterogeneous population containing only $10 \% \mathrm{~T}$ cells as defined by OKT3 monoclonal antibody without any selectivity for either the T4 inducer or T8 suppressor cell subset. Additionally it has been noted that within the $\mathrm{T} \gamma$ subset most mononuclear cells shared reactivity with a monocyte reactive monoclonal antibody, OKM1.30

In the present study we found that 10 out of 17 coeliac disease patients either totally or partially failed to suppress autologous responder cells after Con-A-activation. This is not a consequence of malnutrition, because the defect was present in patients in remission for at least five months who were in normal nutritional status. The defective 
suppressor activity was not associated with a reduction of peripheral $\mathrm{T} 8$ phenotype $\mathrm{T}$ cells. In contrast, there was a reduction of T $\gamma$ subset. The meaning of such a phenomenon is far from clear. It is of interest to note that a significant decrease of this subset has been found also in dermatitis herpetiformis, which is a disease characterised by cutaneous deposits of IgA and asymptomatic gluten sensitive enteropathy. ${ }^{3 P}$ The reduction of this subset has been interpreted as being caused by a more general $\mathrm{Fc}$ receptor defect, including clearance of immune complexes. The abnormal suppressor activity despite the normal percentage of the T8 subset may be explained by one of the following factors: (1) the number of the cells may be normal, but their function may be defective; (2) monoclonal antibodies may detect surface antigens present on resting cells, which may be different from those present on active cells; (3) a suppressor mechanism, not due to T8 cells, mediated by prostaglandin-producing cells may influence Con-Ainducible suppression as suggested by Goodwin et $a l^{29}$ Our preliminary finding that indomethacin, a prostaglandin inhibitor, is able to correct the defective suppressor function of mononuclear cells in coeliac patients favours the third hypothesis. In fact a possible explanation is that in coeliacs an inappropriate adherent cell mediated suppressor function may inhibit the activity of Con-A-inducible suppressor cells as shown in other diseases. ${ }^{29}$ Thus with the Con-A-induced suppression assay we cannot discriminate whether abnormal values in coeliacs are because of abnormal suppressor $\mathrm{T}$ lymphocytes or suppressor monocytes.

Because in a previous investigation, $98 \%$ of our patients were found to be HLA-DR 3- and/or 7-positive, we extended the functional study to normal subjects HLA-matched to our patients. It is known that the frequency of DR 3-and/or 7-positive subjects in our general population is about $55 \% .^{16}$

There was no significant difference in Con-Ainduced suppressor activity between adult controls HLA-matched to patients and randomly selected adult controls, suggesting that HLA-DR 3 and 7 do not interfere directly with Con-A-induced suppression assay.

In conclusion, our data lend additional support to the hypothesis of an immunoregulatory disorder in children with coeliac disease. These findings also indicate the need for further investigation on the role of prostaglandin-producing-adherent cells in the regulation of immune response in coeliac disease.

\section{References}

1 Loeb PM, Ströber W, Falchuck ZM, Laster L.
Incorporation of L-Leucine $-{ }^{14} \mathrm{C}$ into immunoglobulins by jejunal biopsies of patients with celiac sprue and other gastrointestinal diseases. J Clin Invest 1971; 50: 559-69.

2 Falchuck ZM, Laster L, Ströber W. Gluten sensitive enteropathy: intestinal synthesis of anti-gluten antibody in vitro [Abstract]. Clin Res 1971; 19: 390.

3 Auricchio S, Buffolano W, Ciccimarra F, De Vincenzi $\mathrm{M}$, Silano V, Zapponi $\mathrm{G}$. In vitro proliferation of lymphocytes from celiac children and their first-degree relatives in response to wheat gliadin-derived peptides. J Pediatr Gastroenterol Nutr 1982; 1: 515-24.

4 Ashkenazi A, Handzel Z, Idar D, Ofarim M, Levin S. An in vitro immunological assay for diagnosis of coeliac disease. Lancet 1978; 1: 627-9.

5 Douwes FR. Gluten and lymphocytes sensitization in coeliac disease. Lancet 1976; 2: 1353-5.

6 Holmes GKT, Asquith P, Cooke WT. Cell mediated immunity to gluten fraction III in adult coeliac disease. Clin Exp Immunol 1976; 24: 259-65.

7 Sikora K, Anand BS, Truelove SC, Ciclitira PJ, Offord RE. Stimulation of lymphocytes from patients with coeliac disease by a subfraction of gluten. Lancet 1976 ; 2: 389-91.

8 Bullen AW, Losowsky MS. Cell mediated immunity to gluten fraction III in adult coeliac disease. Gut 1978; 18: 126-31.

9 Williamson N, Asquith P, Stokes PL, Jowett AW, Cooke WT. Anti-connective tissue and other antitissue 'antibodies' in the sera of patients with coeliac disease compared with the findings in a mixed hospital population. J Clin Pathol 1976; 29: 484-94.

10 Bullen AW, Hall R, Gowland G, Rayah S, Losowsky MS. Hyposplenism, adult coeliac disease, and autoimmunity. Gut 1980; 21: 28-33.

11 Kenrick KG, Walker-Smith JA. Immunoglobulins and dietary protein antibodies in childhood coeliac disease. Gut 1970; 11: 635-40.

12 Falchuk ZM, Rogentine GN, Ströber W. Predominance of histocompatibility antigen HLA 8 in patients with gluten-sensitive enteropathy. J Clin Invest 1972; 51: 1602-6.

13 Mackintosh P, Asquith P. HLA and coeliac disease. $\mathrm{Br}$ Med Bull 1978; 34: 291-4.

14 Keuning JJ, Pena AS, van Leeuwen A, van Hooff JP, van Rood JJ. HLA-DW3 associated with coeliac disease. Lancet 1976; 1: 506-7.

15 Betuel H, Gebuhrer L, Descos L, Percebois H, Minaire Y, Bertrand J. Adult coeliac disease associated with HLA-DRw3 and DRw7. Tissue Antigens 1980; 15: 231-8.

16 De Marchi M, Borelli I, Olivetti E, et al. Two HLA-D and DR alleles are associated with coeliac disease. Tissue Antigens 1979; 14: 309-16.

17 Tosi R, Vismara D, Tanigaki $\mathrm{N}$ et al. Evidence that coeliac disease is primarily associated with a DC locus allelic specificity. Clin Immunol Immunopathol 1983; 28: 395-404.

18 Robertson DAF, Bullen AW, Losowsky MS. Suppressor cells in splenectomized and coleliac patients [Abstract]. Gut 1980; 21: 915-6.

19 Meeuwisse GW. Diagnostic criteria in coeliac disease. 
Acta Paediatr Scand 1970; 59: 461-3.

20 Pignata C, Vajro P, Troncone R, Monaco G, Ciriaco $M$. Immunoregulatory $T$ subsets in chronic active viral hepatitis. Characterization by monoclonal antibodies. J Pediatr Gastroenterol Nutr 1983; 2: 229-33.

21 Kung PC, Goldstein G, Reinherz EL, Schlossman SF. Monoclonal antibodies defining distinctive human $T$ cell surface antigens. Science 1979; 206: 347-9.

22 Reinherz EL, Kung PC, Goldstein G, Schlossman SF. Separation of functional subsets of human T cells by a monoclonal antibody. Proc Natl Acad Sci USA 1979; 76: 4061-5.

23 Reinherz EL, Kung PC, Goldstein G, Schlossman SF. A monoclonal antibody reactive with the human cytotoxic/suppressor $\mathrm{T}$ cell subset previously defined by a heteroantiserum termed $\mathrm{TH}_{2} . J$ Immunol 1980; 124: $1301-7$.

24 Reinherz EL, Kung PC, Goldstein G, Levey RH, Schlossman SF. Discrete stages of human intrathymic differentiation: analysis of normal thymocytes and leukemic lymphoblasts of T-cell lineage. Proc Natl Acad Sci USA 1980; 77: 1588-92.

25 Breard JM, Reinherz EL, Kung PC, Goldstein G, Schlossman SF. A monoclonal antibody reactive with human peripheral blood monocytes. J Immunal 1980;
124: 1943-8.

26 Reinherz EL, Kung PC, Pesando JM, Ritz, J, Goldstein G, Schlossman SF. Ia determinants on human T-cell subsets defined by monoclonal antibody. Activation stimuli required for expression. J Exp Med 1979; 150: 1472-82.

27 Moretta L, Webb S, Grossi CE, Lydyard PM, Cooper MD. Functional analysis of two human lymphocyte subpopulations: help and suppression of B cell responses by $\mathrm{T}$ cells bearing receptors for IgM or IgG. $J$ Exp Med 1977; 146: 184-200.

28 Shou L, Schwartz SA, Good R. Suppressor cell activity after Concanavalin-A treatment of lymphocytes from normal donors. J Exp Med 1976; 143: 1100-10

29 Goodwin JS. Modulation of Concanavalin-A-induced suppressor cell activation by prostaglandin $\mathrm{E}_{2}$. Cell Immunol 1980; 49: 421-5.

30 Reinherz EL, Moretta L, Roper M, et al. Human T lymphocytes subpopulations defined by $F$ receptors and monoclonal antibodies. A comparison. J Exp Med 1980; 151: 969-74.

' 31 Lawley TJ, Hall RP, Fauci AS, Katz SI, Hamburger MI, Frank MM. Detective Fc-receptor functions associated with the HLA-B8/DRw3 aplotype. $N$ Engl $J$ Med 1981; 304: 185-92. 